\title{
Pengembangan Model Social Media Marketing Dan Keputusan Berkunjung: Sebuah Pendekatan Konseptual
}

\author{
Lalu Edy Herman ${ }^{1}$ dan Handry Sudiartha Athar ${ }^{2}$ \\ ${ }^{1,2}$ Universitas Mataram, ehlalu@gmail.com
}

\begin{abstract}
ABSTRAK
Studi ini berangkat dari adanya masalah pembangunan pariwisata yang semakindipandang sebagaialat pentingdalam meningkatkan pertumbuhan ekonomi. Pengembangan pariwisata tidak terlepas dari strategi pemasaran sebagai upaya pencitraan dengan membangun destinasi pariwisata yang memadai. Sosial media merupakan fenomena terbaru yang memainkan peran penting dalam pemasaran sebuah produk atau layanan sebuah perusahaan, termasuk industri jasa pariwisata. Namun, sejauh mana efektifitas sosial media sebagai strategi promosi perlu untuk dikaji lebih jauh. Penelitian ini bertujuan untuk mengkaji lebih jauh efektivitas penggunaan sosial media dari sudut pandang pelanggan atau komunitas wisatawan dan pengembangan model empirik social media marketing terhadap keputusan berkunjung. Pendekatan studi kasus dan studi pustaka harus dilakukan untuk mengungkap sejauh mana efektivitas social media marketing dalam menjaring wisatawan lokal maupun mancanegara untuk berkunjung. Studi pustaka mencoba mengungkapkan inovasi-inovasi penggunaan sosial media dalam pemasaran industri pariwisata, sedangkan studi kasus berfokus pada pengaruh sosial media pada wisatawan yang berkunjung ke sebuah destinasi wisata. Temuan konseptual menunjukkan kecenderungan wisatawansaat ini mulai beralih ke media sosial untuk membantu merencanakan perjalanan mereka, sekaligus menjadi sumber inspirasi bagi calon wisatawan yang akan melakukan perjalanan wisata.

Kata Kunci: Pariwisata Berkelanjutan, Social Media Marketing, E-WOM, Citra Destinasi, Keputusan Berkunjung
\end{abstract}

\begin{abstract}
This study departs from the problem of tourism development which is increasingly seen as an important tool in increasing economic growth. Tourism development cannot be separated from the marketing strategy as an imaging effort by building adequate tourism destinations. Social media is the latest phenomenon that plays an important role in marketing a product or service of a company, including the tourism services industry. However, the extent to which the effectiveness of social media as a promotion strategy needs to be studied further. This study aims to build the model of social media marketing effectiveness to affect the tourists' visiting decisions. Case study approaches and literature studies must be carried out to reveal the extent of the effectiveness of social media marketing in capturing local and foreign tourists to visit. Literature study tries to reveal innovations in the use of social media in the marketing of the tourism industry, while the case study focuses on the influence of social media on tourists visiting a destination. Conceptual findings show the tendency of tourists to start switching to social media to help their tripsplan, as well as being a source of inspiration for prospective tourists who will travel.
\end{abstract}

Keywords: Sustainable Tourism, Social Media Marketing, E-WOM, Destination Image, Decision to Visit.

Diterima: 20 Juli 2018, Direvisi: 15 Agustus 2018, Diterbitkan: 15 September 2018

ISSN: 2355-0287, E-ISSN: 2549-3299

http://ejournal.bsi.ac.id/ejurnal/index.php/jika 


\section{PENDAHULUAN}

Pengembangan pariwisata berkelanjutan merupakan isu penting dalam industri pariwisata saat ini. Sektor pariwisata merupakan penyumbang Produk Domestik Bruto (PDB) Indonesia dan devisa yang besar serta menciptakan lapangan kerja yang mudah dan murah. Kontribusi devisa pariwisata terhadap penerimaan devisa nasional tahun 2015 sebesar US\$ 12,6 miliar atau $9,3 \%$ secara nasional dan menempati ranking keempat setelah sektor minyak bumi dan gas sebesar US\$18,9 miliar, disusul batu bara sebesar US\$ 16,4 miliar, dan kelapa sawit sebesar US\$ 15,5 miliar. Dari keseluruhan sektor penyumbang devisa negara, hanya sektor pariwisata yang mengalami pertumbuhan positif sebesar $4,8 \%$ sampai dengan 6,9\% (Iza, 2017).

Studi ini berangkat dari adanya masalah pembangunan pariwisata yang semakin dipandang sebagai alat penting dalam meningkatkan pertumbuhan ekonomi, mengurangi kemiskinan, dan memajukan ketahanan pangan. Banyak negara berkembang berhasil meningkatkan partisipasi mereka dalam ekonomi global melalui pengembangan pariwisata internasional (Echtermeyer, 2008), dan juga melalui kebijakan ekonomi untuk mempromosikan pariwisata internasional (Santos and Giraldi, 2017).

Pengembangan pariwisata tidak terlepas dari strategi pemasaran sebagai upaya pencitraan dengan membangun destinasi pariwisata yang memadai, dukungan fasilitas pariwisata, ketersediaan aksesibilitas dan komponen yang tidak boleh dilupakan yaitu peran serta masyarakat. Pemasaran pariwisata menjadi salah satu komponen penting dalam pembangunan pariwisata. Pemasaran pariwisata bertujuan untuk mengupayakan agar sebuah destinasi atau produk pariwisata laku untuk dijual kepada konsumen sehingga tujuan pariwisata dalam hal ini untuk meningkatkan kesejahteraan masyarakat sekitar tercapai. Pemasaran pariwisata ini harus dilakukan secara terus menerus dan berkelanjutan, dengan memperhatikan media iklan yang sesuai dengan target pasar yang dijadikan sasaran pada sebuah obyek wisata yang dapat dimanfaatkan untuk mempertahankan dan meningkatkan tourist retention untuk berkunjung.

Perkembangan teknologi komunikasi sebagai sumber utama informasi dan hiburan juga berdampak pada pergeseran budaya bersosialisasi. Fitur-fitur pada sosial media saat ini menjadi media komunikasi yang paling diminati oleh para pengguna teknologi komunikasi. Pengguna internet di dunia saat ini telah mencapai 4 miliar orang, mengalami kenaikan dari tahun sebelumnya yang hanya 3,8 miliar (We are Social, 2018). Pertumbuhan pengguna internet tersebut tentu saja turut membuat peningkatan terhadap pengguna media sosial. Secara global, pengguna media sosial tumbuh sebesar 13 persen dalam waktu 12 bulan terakhir. Angka yang cukup besar pada pengguna sosial media sehingga berpotensi sebagai media promosi yang dapat digunakan industri, termasuk industri pariwisata.

Sosial media merupakan fenomena terbaru yang memainkan peran penting dalam pemasaran sebuah produk atau layanan sebuah perusahaan. Perkembangan penggunaan sosial media tidak lagi hanya sekedar bentuk eksistensi diri individu saja namun sudah merambah sebagai media promosi di dunia bisnis (Zou, 2018). Saat ini banyak perusahaan yang menerapkan teknologi informasi dalam mendapatkan pelanggan baru, memperbaiki, dan upaya retensi pelanggan (Ge et al., 2013). Upaya perusahaan untuk berinteraksi, berkomunikasi dan melibatkan pelanggannya pada aktivitas yang dilakukan akan dapat memberikan feedback untuk meningkatkan kualitas produk dan pelayanannya. Namun, sejauh mana efektifitas sosial media sebagai strategi promosi perusahaan perlu dikaji lebih jauh. Untuk itu, penelitian ini mencoba melihat efektivitas penggunaan social media dari sudut pandang pelanggan atau komunitas sebuah merek. Selama ini social media hanya digunakan sebagai interaksi dan komunikasi pelanggan dengan perusahaan, namun belum secara serius digunakan sebagai alat untuk mempromosikan sebuah produk atau 
layanan.Sosial media dianggap sebagai media promosi yang efektif dan berbiaya rendah untuk mengelola hubungan dengan pelanggan dan meningkatkan loyalitas pelanggan (Sashi, 2012).

Kelebihan sosial media sebagai media interaktif memberikan pengalaman menarik dalam berkomunikasi, karena pengguna media dapat secara aktif ikut berinteraksi terhadap konten informasi yang diberikan. Konten-konten menarik dan pemberian informasi berupa teks, gambar, audio dan video juga dapat dilakukan sehingga pengguna dapat dengan jelas mengetahui produk dan layanan yang diberikan(Kotler and Keller, 2016). Kecenderungan wisatawansaat ini mulai beralih ke media sosial untuk membantu merencanakan perjalanan mereka, terlebih lagi sudah menjadi sumber inspirasi besar bagi calon wisatawan yang akan melakukan perjalanan wisata. Permasalahan yang mendasar saat ini adalah seberapa jauh efektivitas social media marketing dalam mempengaruhi keputusan berkunjung wisatawan? Bagaimana model pengembangan social media marketing untuk meningkatkan kunjungan wisatawan? Variabel-variabel pendukung social media marketing apa saja yang harus dikembangkan untuk memaksimalkan kunjungan sebuah destinasi wisata?

\section{KAJIAN LITERATUR}

Meningkatnya pengguna internet setiap saat, ternyata tidak diabaikan oleh para pelaku bisnis. Saat ini banyak pelaku bisnis yang membuat website, blog, atau membuat akun di facebook maupun twitter untuk memasarkan produk mereka. Banyak perusahaan yang memanfaatkan sosial media tersebut untuk dapat berinteraksi dan menjalin hubungan dengan pelanggannya. Kemajuan tersebut dirasa sangat bermanfaat untuk dijadikan sebagai salah satu strategi pemasaran bisnis (Duffett, 2017; Huertas and Marine-Roig, 2015). Pemasaran bisnis melalui internet merupakan salah satu cara untuk memperluas jangkauan pasar. Melalui internet marketing, informasi produk perusahaan dapat menjangkau konsumen yang ada di dimanapun tanpa harus terjun langsung ke daerah tersebut untuk mempromosikan produknya(Ukpabi and Karjaluoto, 2017).

Adanya terobosan-terobosan baru pada teknik-teknik pemasaran baru yang diciptakan oleh pelaku bisnis dan didukung oleh internet sangat cepat dalam melahirkan dimensi baru yang disebut sebagai $e$ Marketing(Tham et al., 2013). Menurut (Kalyanam and Mcintyre, 2002), $e$ Marketing ini masih cukup kontroversial sebagai subyek untuk dibicarakan, karena tidak ada yang berhasil menyatukan berbagai teori di sekitarnya, namun ada satu hal di atas yang tidak ada keraguan bahwa $e$-Marketing pertama kali muncul dalam bentuk berbagai teknik yang dikerahkan oleh perusahaan yang menjual produk mereka melalui internet dalam era tahun 1990-an. Menurut Paul (2006) menyatakan bahwa strategi $e$ Marketing biasanya didasarkan dan dibangun atas prinsip-prinsip yang mengatur pemasaran tradisional offline yang selama ini sangat familiar dan telah terkenal diaplikasikan dalam dunia bisnis yang dikenal dengan nama Marketing Mix (4P).Berdasarkan hasil kajian literatur tersebut maka disusunlah sebuah model pengembangan social media marketingyang dapat dilihat pada Gambar 1 dibawah. Model pengembangan social media marketing diupayakan sebagai langkah-langkah pengembangan peningkatan kunjungan wisatawan pada destinasi wisata di Indonesia yang tidak dapat berdiri sendiri dan membutuhkan berbagai dukungan Quadruple-Helix yaitu keterpaduan peran berbagai elemen kunci pengembang pariwisata yaitu pemerintah, akademisi, komunitas dan pelaku usaha untuk perkembangan pariwisata yang berkelanjutan. 


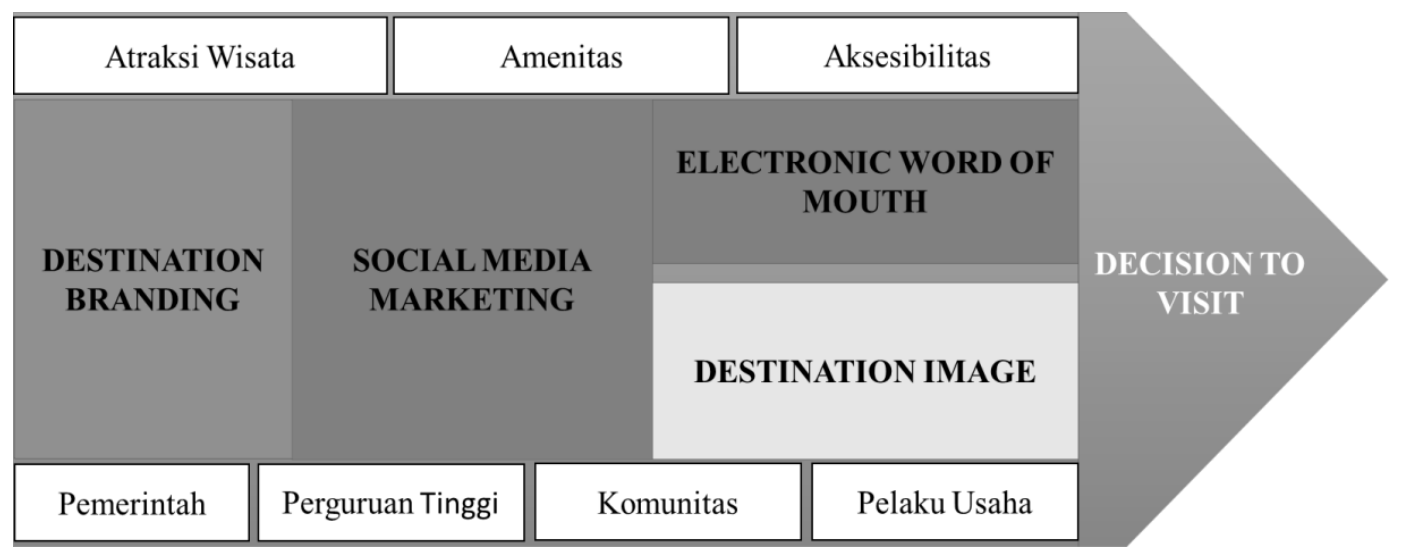

Gambar 1. Model Social Media Marketing Development

\section{Social Media Marketing}

Pada era digital ini, tren promosi sudah berkembang dengan memanfaatkan teknologi. Secara spesifik, tren tersebut kini telah mengarah pada penggunaan sosial media sebagai media promosi. Promosi melalui sosial media dinilai cukup efektif karena tidak membutuhkan biaya yang besar serta memiliki jangkauan lebih luas dibandingkan dengan promosi konvensional, sehingga dapat menjangkau pasar domestik maupun mancanegara dengan waktu yang singkat(Todua, 2017; Ukpabi and Karjaluoto, 2017). Melalui media sosial, perusahaan pun dapat merangkul berbagai segmen pasar karena rentang usia pengguna media sosial tidak hanya sebatas usia remaja, sehingga segmen pasar menjadi lebih dinamis.

Social media marketing(pemasaran melalui sosial media) adalah salah satu bentuk strategi pemasaran dengan memanfaatkan media sosial dalam upaya pemasaran suatu produk/merek dan layanan pada komunitas yang berpartisipasi di media sosial(Lim et al., 2012; Minazzi, 2015; Todua, 2017). Kegiatan SMM pada dasarnya merupakan sebuah upaya menciptakan konten berupa posting, tulisan, gambar, maupun video yang menarik perhatian dan mendorong komunitas untuk berinteraksi dan membagi konten tersebut melalui jaringan sosialnya.Marchiori et al. (2013)berpendapat bahwa sifat interaktif pada sosial media yaitu kemampuannya untuk membangun komunikasi antar individu, perusahaan dalam komunitas penjual dengan pelanggannya, dan melibatkan partisipasi pelanggan dalam mengisi konten dan penciptaan nilai merupakan potensi bagi perusahaan untuk memberikan pelayanan lebih baik bagi pelanggan dan memenuhi kebutuhan mereka. Untuk mencapai tujuan pariwisata, maka karakteristik pesan yang disampaikan melalui media teknologi informasi berperan dalam membentuk kepercayaan terhadap informasi yang diberikan(Duffett, 2017). Karenanya keakuratan informasi dari sumber terpercaya beserta data-data yang akurat berguna untuk memberikan pemahaman, perubahan perilaku serta kepercayaan mengenai informasi yang diterima.

\section{Electronic Word of Mouth (e-WOM)}

Hadirnya sosial media dapat menjembatani kebutuhan aktualisasi diri konsumen dan sosialisasi seperti membentuk komunitas untuk berinteraksi satu dengan yang lainnya. Merek dapat menjadi sarana interaksi untuk bertemu dengan orang lain, membangun relationship, dan menemukan orang-orang yang memiliki minat yang sama. Proses interaksi dan komunikasi dalam sebuah komunitas tersebut akan membentuk kualitas hubungan yang semakin baik antara perusahaan dan pelanggannya, dan pada akhirnya akan menumbuhkan loyalitas pelanggan (González-Rodríguez et al., 2016; Marchioria et al., 2013).

Electronic Word of Mouth (e-WOM) merupakan pernyataan positif dan negatif yang dikemukakan oleh pelanggan potensial, aktual, atau mantan pelanggan mengenai sebuah produk atau perusahaan yang dibuat tersedia untuk banyak orang dan lembaga 
melalui internet (Thurau et al., 2004). Pendapat Thurau et al. (2004) tentang platform bentuk motivasi yang dimiliki konsumen dalam mengartikulasikan apa yang ada di benaknya melalui internet, telah berkembang dan menemukan muaranya sampai sekarang ini. Perilaku melakukan eWOM sangat didasari oleh keinginan interaksi sosial, keinginan akan insentif ekonomi, perhatian pada kebutuhan sesama pelanggan dan potensi dirinya menjadi berharga di mata orang lain adalah bentukbentuk motivasi diri dalam melakukan eWOM(Lončarić et al., 2016; Prayogo et al., 2016; Sotiriadis and Zyl, 2013). Memahami bagaimana motif konsumen akan membantu perusahaan dalam mengelompokkan konsumen dalam menentukan strategistrategi berbeda untuk kelompok-kelompok perilaku dalam melakukan eWOM tersebut (Bae and Kim, 2013). Kemauan melakukan positive e-WOM akan sangat dipengaruhi oleh pengalaman yang telah dirasakan sebelumnya serta pemikiran yang berkembang di benak konsumen sebagai pendorong dalam mendiseminasikan informasi dan pendapat yang dimiliki seorang pelanggan (Jeong and Koo, 2015; Kang and Shin, 2016).

Penelitian-penelitian sebelumnya mengenai e-WOM dalam Social Network Sites (SNSs) mempertegas bahwa perusahaan yang bersegera membentuk fan page dalam sosial media untuk menyediakan wadah pagi konsumennya dalam berinteraksi akan berdampak pada e-WOM merek/produk maupun layanan tertentu pula. Komunikasi eWOM ini melibatkan opini konsumen mengenai produk dan layanan yang diposting di internet (Tham et al., 2013; Thurau et al., 2004).Keterkaitan e-WOM dan penilaian citra destinasi wisata akan sangat dipengaruhi oleh kepercayaan konsumen pada suatu destinasi wisata tertentu. Dari kepercayaan pada merek/produk inilah akan tersedia kemauan yang besar dari konsumen dalam melakukan e-WOM. Adapun faktor e-WOM yang diperhatikan oleh calon wisatawan menurut (Tham et al., 2013)ketika mengadopsi informasi dari internet adalah sebagai berikut:

1. Kredibilitas sumberinformasi e-WOM e-WOM sebagai perpanjangan WOM tradisional sudah menyajikan bentuk baru komunikasi di antara pengirim dan penerima pesan dalam hubungan di dunia maya adalah lemah. Oleh sebab itu, sumber e-WOM yang kredibel sangat penting dalam aktivitas pengambilan keputusan oleh wisatawan.

2. Karakteristik dari sumber pesan

Ulasan-ulasan postingan yang ada sebagian besar dari sudut pandang reviewersehingga karakter reviewer akan menentukan image produk atau layanan yang diulas, sehingga akan turut menentukan keputusan pembelian konsumen.

3. Karakteristik pesan

Pesan-pesan yang disampaikan dalam postingan di sosial media memberikan gambaran produk/layanan yang akan dikonsumsi.Kecenderungan masyarakat dalam menggunakan sosial media dapatmempengaruhi keputusan dalam menentukan suatu tujuan mereka. Orang yang menerima rekomendasi berdasarkan komunikasi dari e-WOM cenderung akan lebih yakin kepada pemberi rekomendasi secara jujur dan tidak ada motif tersembunyi.

\section{Citra Destinasi (Destination Image)}

Citra dari suatu destinasi merupakan bagian penting untuk dijual pada pemangku kepentingan termasuk wisatawan. Citra destinasi merupakan merupakan gambaran, pikiran, kepercayaan, perasaan dan persepsi terhadap suatu destinasi (GonzálezRodríguez et al., 2016). Suatu citra tidak terbentuk dengan sendirinya melainkan dengan persepsi seseorang terhadap suatu objek. Pembentukan citra destinasi wisata dapat berasal dari iklan dan word of mouth, kunjungan ke destinasi wisata, pengalaman yang terbentuk dari destinasi wisata, dan kepuasan atas kunjungan ke destinasi (Hailin et al., 2011). Proses pembentukan sebuah citra destinasi melalui dua hal utama(Echtner 
et al., 2003) yaitu seseorang dapat memiliki citra destinasi meskipun belum pernah mengunjungi karena destinasi tersebut sudah terkenal melalui berbagai media informasi, dan setelah seseorang melakukan kunjungan ke suatu destinasi tersebut.

Terdapat tiga dimensi dari citra destinasi menurut Hailin et al. (2011)yaitu sebagai berikut:

1. Cognitive destination image (citra destinasi kognitif), terdiri dari kualitas pengalaman yang didapatkan/dialami oleh para wisatawan, atraksi wisata yang ada di suatu destinasi wisata, lingkungan dan infrastruktur di lingkungan tersebut, serta hiburan dan tradisi budaya dari destinasi wisata tersebut.

2. Unique image (citra destinasi yang unik), terdiri dari lingkungan alam yang indah, maupun kemenarikan suatu destinasi dan atraksi lokal yang ada di destinasi wisata tersebut.

3. Affective destination image (citra destinasi afektif), terdiri dari perasaanperasaan yang menyenangkan, nyaman, santai dan menarik ketika berada pada suatu destinasi wisata.

\section{Keputusan Berkunjung}

Interaksi konsumen sosial adalah merupakan upaya mereka untuk mendapatkan transparansi dan kebenaran informasi dari kelompoknya maupun perusahaan mengenai merek produk yang mereka gunakan. Evolusi teknologi internet melalui sosial media merupakan sebuah sarana yang dapat memfasilitasi interaksi antara pelanggan dengan perusahaan dan sebagai informasi berharga bagi perusahaan untuk memahami dan memberikan pelayanan yang lebih baik bagi pelanggannya (Sashi, 2012). Perkembangan dan pemanfaatan sosial media sebagai sarana interaksi harus dapat dipahami lebih dalam mengenai dampaknya bagi perusahaan maupun pelanggan (HennigThurau et al., 2013). Nilai interaksi melalui sosial media bagi perusahaan adalah dengan membuat kerangka konseptual dalam mengelola merek(Asseraf and Shoham, 2017)dan pelanggan (Echtermeyer, 2008), dan memanfaatkan potensi pemasaran melalui sosial media (Jeong and Koo, 2015).

Keputusan berkunjung menurut Zhang (2015)dipengaruhi oleh variabel psikologis yang meliputi need, perception, memory dan attitude. Seorang wisatawan berkunjung ke suatu destinasi karena wisatawan tersebut mempunyai kebutuhan untuk berwisata serta mempunyai persepsi yang bagus mengenai destinasi wisata yang dikunjungi. Selain itu memori yang dimiliki dari pengalaman sebelumnya juga berpengaruh. Apabila memorinya indah maka wisatawan tersebut akan memutuskan untuk berkunjung kembali dan merekomendasikan destinasi wisata tersebut kepada orang lain.Adapun proses pengambilan keputusan yang dilakukan pengunjung terdiri dari lima tahap(Kotler and Keller, 2016), yaitu:

1. Pengenalan Kebutuhan

Proses pembelian dimulai ketika seseorang mengenali mengenai kebutuhannya. Timbulnya kesadaran akan kebutuhan terjadi akibat adanya perbedaan yang signifikan antara keadaan yang sebenarya dengan keadaan yang diinginkan.

2. Pencarian Informasi

Pada saat konsumen telah menyadari kebutuhannya, selanjutnya mereka akan mencari solusi untuk memuaskan kebutuhan tersebut melalui pencarian informasi. Adanya pencarian informasi akan menimbulkan beberapa alternatif pilihan..

3. Evaluasi Alternatif Pilihan

Dalam membuat sebuah keputusan, konsumen akan banyak pertimbangan dan selanjutnya mengevaluasi alternatifalternatif pilihan produk/layanan yang ada. Konsumen akan mencari manfaat produk dan membandingkan dengan atribut produk. Selanjutnya, konsumen akan memberikan penilaian yang berbeda untuk setiap atribut produk sesuai dengan kepentingannya. Jika atribut produk memberikan manfaat sesuai dengan yang dicari, maka konsumen akan memberikan perhatian besar pada produk/layanan tersebut. 
4. Keputusan Pembelian

Selama berjalannya proses evaluasi, konsumen akan membentuk preferensi di antara alternatif-alternatif pilihan yang ada. Apabila suatu produk/layanan tersebut dapat memenuhi kebutuhannya, maka konsumen akan mengambil keputusan untuk membeli produk/layanan tersebut.

5. Perilaku Pasca Pembelian

\section{METODE PENELITIAN}

Artikel ini merupakan sebuah kajian konseptual yang dikembangkan dari hasil tinjauan teori yang telah dijelaskan pada telaah literatur dan disesuaikan dengan data empiris yang diperoleh dari wawancara dengan wisatawan yang berkunjung ke Lombok. Lokasi wawancara dilakukan di Bandara International Lombok (BIL) kepada wisatawan yang akan kembali ke daerah/negara asal sebanyak 10 orang dengan berbagai latar belakang dan usia. Dari hasil integrasi antara teori dengan fenomena kunjungan wisatawan di destinasi wisata ini menghasilkan model empirik yang akan dikembangkan lebih jauh secara luas dan sistematis. Pemaparan model dilakukan secara skematik dan pengembangan model empirik untuk penelitian selanjutnya sebagai novelty pada konsep yang dikembangkan dengan nama model Integerated Social Media Marketing.

\section{PEMBAHASAN}

Pemasaran bisnis melalui internet merupakan salah satu cara untuk memperluas jangkauan pasar. Hal ini sejalan dengan penelitian yang dikembangkan oleh Todua (2017) dan Ukpabi and Karjaluoto (2017) bahwa perkembangan internet sejalan dengan laju pertumbuhan pengguna sosial media yang dianggap sebagai media promosi yang efektif dan berbiaya rendah untuk digunakan sebagai alat promosi karena memiliki respon secara langsung dengan penggunanya. Social Strategy digunakan dalam promosi pariwisata pada media sosial merupakan bentuk upaya integrasi antara hubungan
Setelah melakukan keputusan dengan pembelian, maka konsumen akan menilai kinerja produk/layanan yang dikonsumsi dan membandingkannya dengan ekspektasi mereka. Jika lebih rendah dari harapan maka konsumen akan kecewa, jika ternyata sesuai harapan maka konsumen akan merasa puas, dan jika melebihi harapannya maka konsumen akan sangat puas.

pelaku pariwisata dengan wisatawan dapat terjalin dengan baik sehingga dapat mempengaruhi wisatawan lainnya untuk berkunjung, seperti yang dikemukakan oleh Minazzi (2015). Kepuasan wisatawan yang berkunjung pada sebuah destinasi wisata diharapkan dapat mengunggah kegiatankegiatan dan juga obyek destinasi wisata yang ada untuk dilihat oleh follower sehingga pengetahuan tentang destinasi danrespon langsung bisa didapatkan oleh pelakupariwisata dalam membangun strategi komunikasiyang baru maupun strategi pemasarannya. Hal tersebut sejalan dengan pendapat Tham et al. (2013) bahwa hasil dari posting atas sebuah produk atau layanan yang diterima oleh sebuah komunitas pada sosial media dapat berbentukpartisipasi, berbagi dan menciptakan isi dalam sebuah eWOM. Pemahaman e-WOM di bidang marketing bisnis menjadi sangat penting, karena media ini lebih populer pada komunitas online tempat konsumen memiliki potensi untuk menjangkau pangsa pasar global dengan cepat dan mudah untuk mempengaruhi keputusan berkunjung pada sebuah destinasi. Pengembangan model social media marketing untuk menciptakan kekuatan efek e-WOM akan lebih efektif mempengaruhi keputusan berkunjung dengan didukung oleh citra destinasi wisata yang baik.

\section{PENUTUP}

Untuk agenda penelitian mendatang strategi social media marketing terhadap keputusan berkunjung wisatawan dapat dilakukan dengan model yang disajikan pada Gambar 2. 


\section{Gambar 2. Model Empirik Pengaruh Social Media Marketing pada Keputusan Berkunjung}

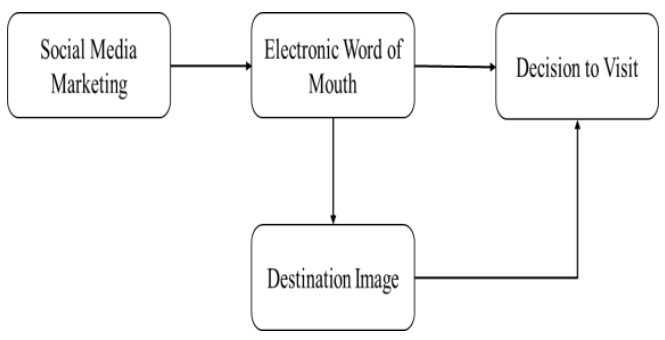

\section{REFERENSI}

Asseraf, Y., and A. Shoham. 2017. Destination branding: The role of consumer affinity. Journal of Destination Marketing \& Management 6 (4):375-384.

Bae, J., and B.-D. Kim. 2013. IS THE ELECTRONIC WORD OF MOUTH EFFECT ALWAYS POSITIVE ON THE MOVIE? Academy of Marketing Studies Journal 17 (1).

Duffett, R. G. 2017. Influence of social media marketing communications on young consumers' attitudes. Young Consumers 18 (1):19-39.

Echtermeyer, M. 2008. Brands as Destinations - The New Tourism Objective for Chinese Tourists. Stockinger, $J$.

Echtner, C. M, and J. R. B. Ritchie. 2003. The meaning and measurement of destination image. The Journal of Tourism Studies 14 (1).

Ge, J., U. Gretzel, and R. J. Clarke. 2013. Strategic Use of Social Media Affordances for Marketing: A Case Study of Chinese DMOs. Information and Communication Technologies in Tourism.

González-Rodríguez, M. R., R. MartínezTorres, and S. Toral. 2016. Post-visit and pre-visit tourist destination image through eWOM sentiment analysis and perceived helpfulness. International Journal of
Contemporary

Hospitality

Management 28 (11):2609-2627.

Hailin, Q., K. L. Hyunjung, and I. H. Hyunjung. 2011. A model of destination branding: Integrating the concepts of the branding and destination image. Tourism Management 32 (3):465-476.

Hennig-Thurau, T., S. Fuchs, and M. B. Houston. 2013. What's a Movie Worth? Determining the Monetary Value of Motion Pictures' TV rights. International Journal of Arts Management 15 (3).

Huertas, A., and E. Marine-Roig. 2015. User reactions to destination brand contents in social media. Information Technology \& Tourism 15 (4):291315.

Iza, N. 2017. Pariwisata Sumbang Devisa Terbesar Kedua. Kementerian Komunikasi dan Informatika Republik Indonesia.

Jeong, H.-J., and D.-M. Koo. 2015. Combined effects of valence and attributes of e-WOM on consumer judgment for message and product: The moderating effect of brand community type. Internet Research 25 (1):2-29.

Kalyanam, K., and S. McIntyre. 2002. The E-marketing Mix: A Contribution of the E-tailing Wars. Journal of the Academy of Marketing Science 30 (4).

Kang, M., and D.-H. Shin. 2016. The effect of customers' perceived benefits on virtual brand community loyalty. Online Information Review 40 (3):298-315.

Kotler, P., and K. L. Keller. 2016. Marketing Management. edited by 15th: Pearson Education, Inc.

Lim, Y., Y. Chung, and P. A. Weaver. 2012. The impact of social media on destination branding. Journal of Vacation Marketing 18 (3):197-206.

Lončarić, D., I. Ribarić, and V. Farkaš. 2016. THE ROLE OF ELECTRONIC WORD-OF- 
MOUTH IN THE TOURISM MARKET. Tourism \& Hospitality Industry:188-203.

Marchiori, E., L. Cantoni, and D. R. Fesenmaier. 2013. What did they say about us? Message Cues and Destination Reputation in Social Media. Information and CommunicationTechnologies in Tourism:170-182.

Marchioria, E., P. Milwood, and F. Zach. 2013. Drivers and Benefits of Analysing DMOs' eWOM Activities. In Information and Communication Technologies in Tourism, edited by L. C. a. Z. X. (eds.): Springer-Verlag Berlin Heidelberg.

Minazzi, R. 2015. Social Media Marketing in Tourism and Hospitality. London: Springer Cham Heidelberg New York Dordrecht London.

Paul, P. 2006. Marketing on the Internet. Journal of Consumer Marketing 13 (4):27-39.

Prayogo, R. R., F. L. S. Ketaren, and R. M. Hati. 2016. Electronic Word Of Mouth, Destination Image, And Satisfaction Toward Visit Intention : An Empirical Study In Malioboro Street, Yogyakarta. Advances in Social Science, Education and Humanities Research (ASSEHR) 81.

Santos, G. E. d. O., and J. d. M. E. Giraldi. 2017. Reciprocal effect of tourist destinations on the strength of national tourism brands. Tourism Management 61:443-450.

Sashi, C. M. 2012. Customer engagement, buyer-seller relationships, and social media. Management Decision 50 (2):253-272.

Sotiriadis, M. D., and C. v. Zyl. 2013. Electronic word-of-mouth and online

\section{BIODATA PENULIS}

Dr. Lalu Edy Herman Mulyono, SE., MM adalah seorang dosen dan peneliti di Fakultas Ekonomi dan Bisnis Universitas Mataram. reviews in tourism services: the use of twitter by tourists. Electron Commer Res 13:103-124.

Tham, A., G. Croy, and J. Mair. 2013. Social Media in Destination Choice: Distinctive Electronic Word-ofMouth Dimensions. Journal of Travel \& Tourism Marketing 30 (12):144-155.

Thurau, T. H., K. Gwinner, G. Walsh, and D. D. Gremler. 2004. Electronic Word-of-Mouth via ConsumerOpinion Platforms: What Motivates Consumers to Articulate Themselves on the Internet? Journal of Interactive Marketing 18 (1).

Todua, N. 2017. Social Media Marketing for Promoting Tourism Industry in Georgia. In The 22nd International Conference on Corporate and Marketing Communications

Challenges of Marketing Communications in a Globalized World. Faculty of Economics and Business, University of Zaragoza, Zaragoza (Spain), May 4-5, 2017.

Ukpabi, D., and H. Karjaluoto. 2017. Influence of Social Media on Corporate Heritage Tourism Brand.697-709.

Zhang, L. 2015. The effect of social media marketing on brand marketing and communication strategy: the case of Visit Denmark, Program: Communication and Business Studies, Roskilde University.

Zou, S. S. 2018. Marianna Sigala and Ulrike Gretzel (eds.): Advances in social media for travel, tourism and hospitality: new perspectives, practice and cases. Inf Technol Tourism 18:187-189.

Dr. Handry Sudiartha Athar, SE., MM adalah adalah seorang dosen dan peneliti di Fakultas Ekonomi dan Bisnis Universitas Mataram. 